\title{
sciendo
}

Current Issues in Pharmacy and Medical Sciences

Formerly ANNALES UNIVERSITATIS MARIAE CURIE-SKLODOWSKA, SECTIO DDD, PHARMACIA

journal homepage: http://www.curipms.umlub.pl/

\section{Protective role of quercetinum in mercury exposure cardiotoxity}

\author{
RostysLAV F. KAMINSKY*
}

O.O. Bogomolets National Medical University, Department of Histology and Embryology, T. Shevchenko 13, Kyiv 01601, Ukraine.

\begin{tabular}{|c|c|}
\hline ARTICLE INFO & ABSTRACT \\
\hline $\begin{array}{l}\text { Received } 28 \text { April } 2018 \\
\text { Accepted } 22 \text { November } 2018\end{array}$ & $\begin{array}{l}\text { The article describes the remediation of myocardium structure characteristics provided } \\
\text { by Quercetinum under the influence of } 0.01 \text { LD50 mercury chloride (II) in rats at chronic }\end{array}$ \\
\hline $\begin{array}{l}\text { Keywords: } \\
\text { quercetinum, } \\
\text { mercury chloride, } \\
\text { chronic exposure, } \\
\text { myocardium, } \\
\text { rats. }\end{array}$ & $\begin{array}{l}\text { exposure. Ultrastructural and metabolic reorganization of myocardium tissue was studied } \\
\text { by electron microscopic and histochemical techniques. Quercetinum reduces energy } \\
\text { imbalance in the myocardium, shows membrane-stabilizing activity, and promotes } \\
\text { stabilization and normalization of the function of membranes by direct biochemical } \\
\text { interaction of the membrane organelles of the body's cells. }\end{array}$ \\
\hline
\end{tabular}

\section{INTRODUCTION}

In recent years, significant factual material has accumulated that shows that heavy metals can substantially affect the function, metabolism and structure of the nervous system, heart and blood vessels, as well as other systems [1-6]. These metals affect various aspects of cardiovascular system function by blocking enzyme systems to a certain extent, leading to the formation of free radicals [7].

Flavonoids that exhibit antioxidant properties inhibiting the formation of free radicals [8-13] are of particular importance in the prevention of cardiovascular diseases. One flavonoid already in pharmacology use is Quercetin. It manifests its antioxidant activity through its complex formation with bi- and trivalent heavy metals that are included in the catalytic centers of redox enzymes $\left(\mathrm{Fe}^{3+}, \mathrm{Cu}^{2+}\right)$ and nitrogen-containing exo- and endotoxins [14]. In our work, a two-week exposition (10 administrations) was conducted in order to assess initial changes in nervous system activity [16], and ascertain whether such research is relevant in a ten-week term (50 administrations) study of the special characteristics of mercury neuro-toxicity.

The aim of this study was to evaluate the myocardium morphofunctional changes under chronic exposure to small doses of mercury (II) chloride and to assess the efficacy of Quercetinum administration against a backdrop of mercury intoxication modeling.

\footnotetext{
${ }^{\star}$ Corresponding author

e-mail: email: lisusha88@gmail.com
}

\section{MATERIALS AND METHODS}

The experiments were carried out on 30 male Wistar rats weighing 100-150 $\mathrm{g}$ (at the beginning of the experiment) with simulated chronic toxic cardiomyopathy by intraperitoneal injection of mercury (II) chloride solution at a dose of 0.01 LD50 during a 10-week period. These animal experiments were carried out in accordance with the Law of Ukraine "On protection of animals from cruelty" (2006), "General ethical principles of animal experiments", adopted by the First National Congress on Bioethics (Kiev, 2001).

The animals were grouped as: intact animals (C) which were administered with saline solution (control group, 10 animals), rats after exposure to small doses of mercury without antioxidant drugs administration (I); rats with daily administration of Quercetinum $(0.001 \mathrm{mg} / 100 \mathrm{~g}$ of body mass) during two weeks immediately after the end of mercury chloride exposure [23]. During the experiment, we studied the cardioprotective effect of Quercetinum (quercetin, production of CJSC "Borshchagov Chemical and Pharmaceutical Plant”, Ukraine).

Quercetinum is known to suppress the activity of phosphodiesterase. This substance promotes cyclic adenosine monophosphate (cAMP) accumulation in the cells of the main intracellular mediator and brings about antioxidant, antitoxic, antihypertensive, hypolipidemic immunoregulating, capillary suppressing effects [18-20]. At the same time, Quercetinum eliminates the retraction of the endothelium and edema of the intima - factors that expand the inter-endothelial gaps [21].

All groups of animals were put out of the experiment under ether narcosis (in accordance with "http:// web.jhu.edu/animalcare/policies/ether.html”'t “_blank") followed by decapitation with the following examination 
by histochemical, morphometric and electron microscopic methods.

Ultrathin sections were obtained by means of LKB ultratome III (Sweden) and Reichert microtome (Sweden) and contrasted with saturated $2 \%$ uranyl acetate and lead citrate and were then examined under the transmission electron microscope (TEM- 125K, Ukraine).

The purpose of histochemical examination was to: (1) investigate the activity of succinate dehydrogenase, EC 1.3.5.1 (SDH) by applying the method of Nahlas et al. and the activity of cytoplasmic 6-glycerophosphate dehydrogenase and L-lactate dehydrogenase, EC 1.1.1.27 (LDH) by way of the method of Gress, Scarpelli and Pierce; (2) to study NAD-H-DH and NADPH-DH as the indicators of activity of all NADPH-H-generating dehydrogenases [15]. The intensity of the histochemical reactions was determined in activity units (a.u.) by semi-quantitative assay [16].

We used the "Organelle" program (electron microscopy laboratory of the Institute of pathology problems of O.O. Bogomolets NMU) for morphometric studies.

In the obtained cardiomyocytes, the average area $\left(10^{-2} \mathrm{mcm}^{2}\right)$ of mitochondria, mitochondrial volume $(\%)$ and quantitative $\left(10^{-2} \mathrm{mcm}^{2}\right)$ density were measured, as well as the mitochondrial form factor, the average number of crista in one mitochondria, total (micron) and average ( $\mathrm{mm}$ ) length of crista membranes in one mitochondria, the crista quantitative density (\%) and the distribution of mitochondria in area in cardiomyocytes according to the principles of stereometric analysis [17]. The average value (M) and the standard deviation $(\mathrm{m})$ were determined.

Statistical analysis of the results was conducted by means of Statistic for Windows 6.0 package (Microsoft Corporation, USA) using parametric and nonparametric methods of results evaluation. The differences with a significance level of more than $95 \%(p<0.05)$ were considered to be reliable.

\section{RESULTS}

Study of the features of morphological, ultrastructural, histochemical changes of the myocardium and statistical processing of morphological data in chronic mercuric exposition has shown that the dynamics of energy metabolism (decrease in the level of enzymes of respiration and terminal oxidation activity combined with the increase of glycolytic processes) in a complex with detected changes in small branches of coronary vessels and vessels of microvascular bed, may indicate the development of signs of tissue hypoxia

Table 1. Morphometric parameters $(\mathrm{M} \pm \mathrm{m})$ of mitochondria in cardiomyocytes of rats after chronic exposure to small doses of mercury

\begin{tabular}{|c|c|c|c|c|}
\hline Groups & $\begin{array}{c}\text { Mitochondrial } \\
\text { volume density, } \\
\%\end{array}$ & $\begin{array}{c}\text { Mitochondrial } \\
\text { quantitative } \\
\text { density, } \\
10^{-2} / \mu \mathrm{m}^{2}\end{array}$ & $\begin{array}{l}\text { Mitochondrial } \\
\text { sections area, } \\
10^{-2} / \mu \mathrm{m}^{2}\end{array}$ & $\begin{array}{l}\text { Mitochondrial } \\
\text { form factor }\end{array}$ \\
\hline $\begin{array}{l}\text { Control } \\
(n=10)\end{array}$ & $30.3 \pm 2.9$ & $51.1 \pm 5.2$ & $41.3 \pm 2.0$ & $0.81 \pm 0.02$ \\
\hline $\begin{array}{c}I \\
(n=10)\end{array}$ & $14.60 \pm 3.03 *$ & $22.90 \pm 5.55^{*}$ & $48.6 \pm 3.4$ & $0.75 \pm 0.01$ \\
\hline $\begin{array}{c}\text { II } \\
(n=10)\end{array}$ & $28.2 \pm 4.8^{\#}$ & $33.6 \pm 3.3^{*}, \#$ & $73.11 \pm 4.02 *$, \# & $0.79 \pm 0.01$ \\
\hline
\end{tabular}

in myocardium in chronic mercurial exposure. This may also indicate disorder of the mitochondrial apparatus and a violation of the permeability of its membranes that confirms the distortion of the volume-spatial relations of mitochondria (Tables 1 and 2) with a histologically detected decrease in the activity of SDH and NAD-H-DH and the growth of LDH activity (Fig.1) [16].

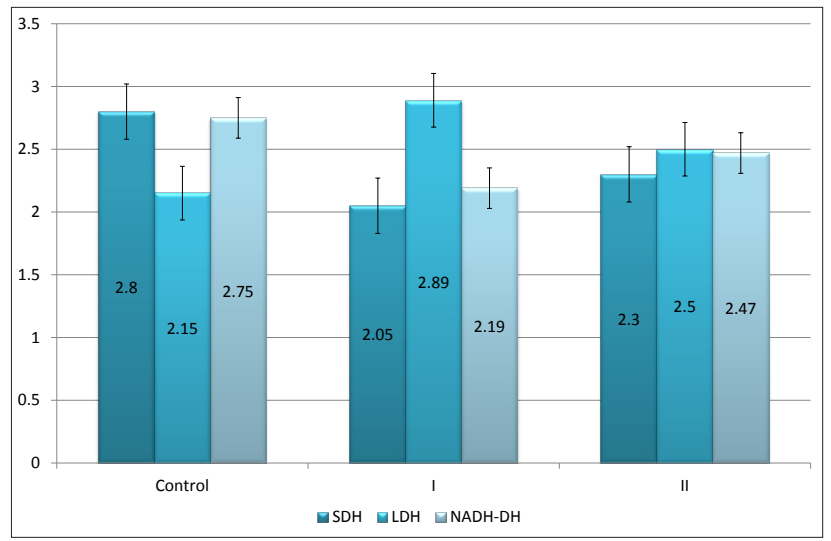

Figure 1. Histochemical parameters $(\mathrm{M} \pm \mathrm{m})$ of redox enzymes activity in the myocardium of the rats' hearts. The horizontal axis - groups of studied animals; the vertical axis - the activity of redox enzymes (a.u.)

Using Quercetinum in chronic exposure, we observed that blood capillaries retain a structural organization and have a thinning endothelium. Moreover, some of the capillaries might have acutely narrowed lumen, and the inner lining has a convoluted look. In cardiomyocytes, the activation of the protein synthetic processes is observed, as evidenced by the development of rough endoplasmic reticulum and the accumulation of free ribosomes, but there are contractions of myofibrils, dystrophically altered mitochondria, lysis of sarcolemma, while some cardiomyocytes have a slightly increased number of transport structures (micropinocytotic vesicles).

In cardiomyocytes under treatment with Quercetinum, there are mitochondria with more preserved external membrane and crista. The number increases and the average cross-section area is enhanced as well, in comparison with the animals without drug correction, due to the decreased number of small and large forms in relation to distribution in animals without pharmacological effects (Table 1). Total crista length in one mitochondria and quantity of cristae in one mitochondrion are also increased, in comparison with untreated animals. Correlation analysis confirms that in

Table 2. Morphometric parameters $(\mathrm{M} \pm \mathrm{m})$ of cristae in cardiomyocytes mitochondria of rats after chronic exposure to small dose of mercury

\begin{tabular}{|c|c|c|c|c|}
\hline Groups & $\begin{array}{c}\text { Quantity of } \\
\text { cristae in one } \\
\text { mitochondrion }\end{array}$ & $\begin{array}{c}\text { Quantitative } \\
\text { density of } \\
\text { cristae, } \%\end{array}$ & $\begin{array}{c}\text { Total length } \\
\text { of cristae } \\
\text { membranes } \\
\text { in one } \\
\text { mitochondrion, } \\
\mu \mathrm{m}\end{array}$ & $\begin{array}{c}\text { Average } \\
\text { length of crista } \\
\text { membrane, } \mu \mathrm{m}\end{array}$ \\
\hline $\begin{array}{c}\text { Control } \\
(\mathrm{n}=10)\end{array}$ & $26.9 \pm 1.1$ & $5.4 \pm 0.9$ & $48.6 \pm 3.6$ & $18.8 \pm 0.2$ \\
\hline $\begin{array}{c}\text { I } \\
(\mathrm{n}=10)\end{array}$ & $6.09 \pm 1.19 *$ & $0.57 \pm 0.14 *$ & $26.01 \pm 2.86 *$ & $6.58 \pm 0.36 *$ \\
\hline $\begin{array}{c}\text { II } \\
(n=10)\end{array}$ & $27.42 \pm 2.61 *, \#$ & $3.01 \pm 0.87 *, \#$ & $32.39 \pm 2.49 *, \#$ & $10.03 \pm 0.21 *, \#$ \\
\hline
\end{tabular}


the mitochondria of cardiomyocytes of exposed rats under the influence of Quercetinum, there is an increase in the number of crista in direct proportion to the size of the mitochondria in which they are located (Table 2).

Histomorphological studies have also established the growth of the activity of tissue respiratory enzymes (SDH) in relation to the group without pharmacological effects, and the indicators of terminal oxidation (NAD-H DH, NADP-H DH) and LDH (Fig. 1) do not have statistically significant differences with control. Consequently, Quercetinum in prophylactic administration induces a decrease in the intensity of energy and structural disorders of cardiomyocytes, in comparison with the group without pharmacological effects.

\section{DISCUSSION}

The myocardium state observation under Quercetin administration in the presented experiment has shown most of the morphological characteristics of myocard pathology to be unchanged in the blood stream, interstitium and cardiomyocytes. In the experiment, we observed a combination of microscopic signs of edema, contractual and dystrophic changes at the morphometric level, as well as the restoration of cell metabolic and synthetic apparatus at the electron microscopy level.

Morphometric analysis of the mitochondrial area showed a Gauss distribution wherein middle-size organelles dominate, while the presence of small and large organelles was generally equal. This leads to normalization of mitochondrial volume density. What is more, indicators of terminal oxidation showed restoration of cell energy apparatus function.

Consequently, in contrast to experimentation on the use of Quercetinum in subchronic exposure to mercuric chloride, these results reveal that the compound is antioxidant and membrane stabilizing, as well as cell regenerating [23].

The differences between the results of these two works include:

- Lack of blood circulation disorders such as venous and haemo-micro-circulatory congestion, hemorrhages, plasmatic impregnation of vascular wall in comparison to subchronic exposure and use of Quercetinum,

- Processes of new-formed mitochondria expression in cardiomyocytes under Quercetinum administration after subchronical mercury chloride exposition are inhibited 10 weeks after exposition,

- Activity index of SDH is lower and index of NAD-H-DG increases in comparison to the level of these indexes under Quercetinum administration in conditions of subchronic intoxication. This is evidence of the restoration of disordered metabolic processes.

Literature also shows that according to clinical trials, Quercetinum can prevent myocardial ischemia and Q-T interval dispersions due to cardiotoxic effects of small cumulative doses of anthracycline antibiotics. Moreover, it can reduce their severity at high doses [22].

Consequently, we have shown that Quercetinum reduces energy imbalance in the myocardium and exhibits membranestabilizing action. Furthermore, it promotes stabilization and normalization of the function of membranes by the direct biochemical interaction of these important components of the body's cells. These results confirm the data on shortrange exposure to mercury chloride, under which it was revealed [23].

\section{CONCLUSIONS}

Quercetinum reduces energy imbalance in the myocardium, exhibits membrane-stabilizing action and promotes stabilization and normalization of the function of membranes by direct biochemical interaction of the membrane organelles of the body's cells.

\section{ORCID iDs}

Rostyslav Kaminsky Dhttps://orcid.org/0000-0001-5744-7581

\section{REFERENCES}

1. Omelchuk ST, Aleksijchuk VD, Sokurenko LM, Blagaia A, Prudchenko S. Characteristics of rat liver exposed to nanoparticles of lead compounds. Georgian Med News. 2016;261:94-9.

2. Omel'chuk ST, Aleksiřchuk VD, Sokurenko LM. Biochemical parameters of blood and morpho-functional state of the liver of experimental animals by the actions of lead sulfide nanoparticles in different time study. Likars'ka sprava. 2014;3-4:114-8.

3. Busch J. Knödler M, Kühn M, Lipinski A, Steinhoff B. The heavy metals cadmium, lead and mercury in raw materials of animal origin: evaluation of data from practice. Pharmeur Bio Sci Notes. 2015;2015:150-65.

4. Aleksiichuk V, Omelchuk S, Sokurenko L, Kaminsky R, Kovalchuk O, Chaikovsky Y. The influence of lead nanoparticles on the morpho-functional changes of rat liver during the postexposure period. Microsc Res Tech. 2018;81:781-788. doi: 10.1002/jemt.23036.

5. Lavrinenko VE, Zinabadinova SS, Shobat LB, Sokurenko LM, Chaikovsky YuB. Influence of nanodiamonds and carbon nanowires on survival and cells structure in chicken embryo. Georgian Medical News. 2016;6(255):93-9.

6. Rizzetti, DA, da Silva TM, Escobar AG, et al. Mercury-induced vascular dysfunction is mediated by angiotensin II AT-1 receptor upregulation. Environ Res. 2018;162:287-96, doi: 10.1016/j.envres. 2018.01.026.

7. Bernhoft RA. Mercury toxicity and treatment: a review of the literature. J Environ Public Health. 2012;2012: 460508. doi: 10.1155/ 2012/460508.

8. Foras LD. Quercetin in treatment of cardio-vascular diseases. The radical Research. 2005;39:1052-76.

9. Li G, Zhang H, Li Y, Wang Y. Protection of vascular endothelial cells from high glucose injury induced by quercetin. Zhong Yao Cai. 2002;25(4):268-70

10. Sokurenko LM, Chaikovskii YuB. Mildronate protects neuroblasts against toxic influence of mercuric chloride in cell culture. Neurophysiology, 2014;46(3):271-3. https://doi.org/10.1007/s11062 $-014-9440-7$

11. Sokurenko LM, Chaikovskii YuB. Protective effects of Thiotriazolinum and Mildronate against mercury chloride toxicity in neuroblastoma cell culture Neurophysiology 2016;48(3):171-5. https://doi.org/10.1007/s11062-016-9585-7. Available from: http:// link.springer.com/article/10.1007/s11062-016-9585-7

12. Sokurenko LM, Savchyna MO, Litus VI, Kaminsky RF, Chaikovsky YB. Rat spinal ganglia in assessment of protective action of antioxidants: A morphological study Medicina (Kaunas). 2017;53(4): 217-23. https://doi.org/10.1016/j.medici.2017.11.001

13. Jain AK, Mehra NK, Swarnakar NK. Role of Antioxidants for the Treatment of Cardiovascular Diseases: Challenges and Opportunities. Curr Pharm Des. 2015;21(30):4441-55.

14. Maksutina NP. Antioxidant Properties of Quercetin. Pharm J. 1993;6:42-3. 
15. Pierce E. Histochemistry theoretical and applied. M. Foreign Literature; 1962.

16. Kamynsky R, Primachenko V, Sokurenko L, Chaikovsky Y. A study of impact of mercury chloride on myocardium in experiment. Georgian Med News. 2016;251:64-70.

17. Avtandilov GG. Fundamentals of quantitative pathological anatomy. Moscow, Meditsina Publ, 2002;240 p.

18. Chekman IS. Clinical herbal medicine. Kyiv: Kolos;1993:383.

19. Toronchenko OM, Istomin FM. Application of quercetin in the complex treatment of patients with coronary heart disease with concomitant dyscirculatory encephalopathy. Materials of the III Republican Scientific and Practical Conference «New in Clinical Pharmacology and Pharmacotherapy of Diseases of Internal organs» Kharkiv. 2000;127-9.
20. Ballmann C, Hollinger K, Selsby JT, Amin R, Quindry JC. Histological and biochemical outcomes of cardiac pathology in $\mathrm{mdx}$ mice with dietary quercetin enrichment. Exp Physiol. 2015;100(1): $12-22$.

21. Dovgan RS, Chekman IS. Morphological changes of hypertension rat myocardium at antihypertensive and metabolic pharmacocorrection. Modern science - moderni veda. 2015;2:168-73.

22. Vatutin NT, Zakhama S. The role of quercetin in preventing the onset of silent myocardial ischemia due to the chronic cardiotoxic effects of anthracycline antibiotics. Questions of Experimental and Clinical Medicine. 2007;11(1):14-8.

23. Kaminsky F. Rostislav, Sokurenko M. Liudmyla, Chaikovsky B. Yuri Status of rats myocardium under subchronic mercury exposure and its pharmacological correction. Curr Issues Pharm Med Sci., 2016;29(4):167-70. 